\title{
Performance of reduced herbicide doses in spring cereals
}

\begin{abstract}
JUKKA SALONEN
SALONEN, J. 1993. Performance of reduced herbicide doses in spring cereals.Agric. Sci. Finl. 2: 537-550. (Agric. Res. Centre of Finland, Inst. Plant Prot., FIN-31600 Jokioinen, Finland.)

The consequences of dose reduction of three new herbicide formulations were studied for the control of annual broad-leaved weeds in fields of spring barley (Hordeum vulgare L.) and spring wheat (Triticum aestivum L.). The herbicide formulations were MCPA/mecoprop-P, MCPA/dichlorprop-P and MCPA/fluroxypyr. The efficacy of the lowest recommended dose and a $30 \%$ lower rate were tested and compared with the reference herbicide tribenuron-methyl. Trials were conducted at seven sites for three years. Considerable annual fluctuations in weed infestation were recorded. Although the dose reduction occasionally caused considerable decline in control (on \%-scale), suppression of weed biomass was still satisfactory in most of the trials. On average, a $75 \%$ reduction of weed biomass in spring barley and an $83 \%$ reduction in spring wheat were achieved with reduced herbicide doses. Use of reduced herbicide doses for three years in the same fields caused neither a significant increase in weed infestation nor changes in the species composition of weed populations compared with treatments at recommended rates of application. There was a significant difference in biomass production between weed species. Consequently, the total biomass production of annual dicotyledonous weeds correlated only weakly $(r=0.48)$ with the total weed density. Even in untreated plots the weed biomass at harvest constituted, on average, only $3.1-3.6 \%$ of the total vegetative biomass of crop stands. Thus, the crop yield responses to chemical weed control remained low.
\end{abstract}

Key words: spring barley, spring wheat, broad-leaved weeds, MCPA/mecoprop-P, MCPA/dichlorprop-P, MCPA/fluroxypyr, tribenuron-methyl

\section{Introduction}

Reduced herbicide doses have provided adequate control of broad-leaved weeds in many recent cereal experiments (e.g. BAANDRUP and BALLEGAARD 1989, DAVIES et al. 1989, FoGELFORS 1990, KEMMER and Hurle 1990, Proven et al. 1991, SALONEN 1992a). At present, political Action Plans stipulate the reduction of pesticide use in the Nordic countries (THONKE 1991, Ympäristöministeriö 1992). Reduction of herbicide doses is one of the measures suggested and studied to achieve this objective.

In the Nordic countries (Denmark, Finland, Norway, Sweden), herbicides represent $60-80 \%$ of total pesticide use (THONKE 1991, MARKKULA et al. 1990). Herbicides are commonly used to control broad-leaved weeds in fields of small-grain cereals, which represent the most widely cultivated crops. Therefore, special attention is paid to optimization of herbicide use in cereal fields as cereals are probably able to out-compete weeds even at low rates of herbicide application. 
The recommended herbicide doses given on the product labels are normally suggested by chemical companies and then officially tested and approved by the relevant national authorities. The recommended "normal" dose implicitly ensures reliable weed control in most situations. The use of factoradjusted doses is, however, emphasized by the extension service and computer-based advisory systems (KUDSK 1989, BAANDRUP and BALLEGAARD 1989, JENNÉUS 1991).

Formulated mixtures of MCPA/dichlorprop and MCPA/mecoprop are commonly used in spring cereal crops in Finland (HYNNINEN and BLOMQVIST 1993). To date, the commercial formulations of phenoxypropionic acids, dichlorprop and mecoprop, have been mixtures of two optical isomers, $\mathrm{R}^{(+)}$and $\mathrm{S}^{(-)}$. However, only the $\mathrm{R}^{(+)}$isomer is an active part of herbicide. Recently, these isomers have been separated, and formulations containing only the active isomer have been developed (SQUIRES et al. 1987). Replacement of conventional racemic isomers by the new active isomers, dichlorprop-P and mecoprop-P, results in approximately $50 \%$ reduction in the use of the active ingredients, dichlorprop and mecoprop. The first commercial products containing active isomers were registered in Finland in 1992.

The purpose of this study was to investigate possibilities for reducing the lowest recommended application rates of the new cereal herbicides by $30 \%$. The risk of failure was assessed, and the consequences of continuous use of reduced herbicide doses on weed infestation were studied. Furthermore, crop yield responses to chemical weed control were measured.

\section{Material and methods}

Field experiments were conducted at seven experimental stations of the Agricultural Research Centre. Four stations (Anjalankoski (KYM), Jokioinen (RKA), Kokemäki (SAT) and Mietoinen (LOU)) are located in southern Finland and three stations (Mouhijärvi (SAH), Pälkäne (HÄM) and Ylistaro (EPO)) in central Finland. The same trial protocol was used for three years, 1989-1991, in spring bar- ley and spring wheat monocultures in the same field. At each site there was one spring wheat (cv. 'Luja') trial and at four sites (EPO, KYM, LOU, RKA) there was a spring barley (cv. 'Pohto') trial. Thus, during the 3-years of experimentation there were in total 21 spring wheat trials and 11 spring barley trials.

The experiments were established in 1989 in fields where spring cereals were sown in 1988. The crops were sown at the recommended seed rates: 450 viable seeds of barley and 600 seeds of wheat $\mathrm{m}^{-2}$. Various soil types from ranging from sandy clay to heavy clay were represented. The experimental plots $(4.0 / 5.0 \mathrm{~m} \mathrm{x} 12 \mathrm{~m})$ were ploughed to a depth of $20-25 \mathrm{~cm}$ every autumn.

Commercial herbicide formulations of MCPA/mecoprop-P (270/305 g a.i. $\mathrm{I}^{-1}$, 'Duplosan $\mathrm{KV}-\mathrm{M}^{\prime}$ ) for use in wheat fields and MCPA/dichlorprop-P (265/285 g a.i. I $^{-1}$, 'Duplosan DP-M') in barley fields were applied at their lowest recommended rates and at $30 \%$ lower rates. MCPA/fluroxypyr (400/100 g a.i. l $^{-1}$, 'Starane M') was applied to both crops. In addition, tribenuronmethyl (750 $\mathrm{g} \mathrm{kg}^{-1}$ granular formulation, 'Express 75 DF') (FERGUSON et al. 1985) was used as a reference herbicide (Table 1).

New formulations of phenoxy acid herbicides containing only the optically active isomers of dichlorprop and mecoprop (SQUIRES et al. 1987) were

Table 1. Treatments in the field experiments in spring barley and spring wheat fields in 1989-1991. MCPA/dichlorprop-P was applied only in spring barley and MCPA/mecoprop-P only in spring wheat.

\begin{tabular}{|c|c|c|}
\hline \multirow[t]{2}{*}{ Treatment } & \multicolumn{2}{|c|}{ Herbicide dose } \\
\hline & $1 \mathrm{ha}^{-1}$ & g a.i. ha \\
\hline Unsprayed & 0 & \\
\hline MCPA/fluroxypyr & 0.70 & $280 / 70$ \\
\hline MCPA/fluroxypyr & 1.00 & $400 / 100$ \\
\hline MCPA/dichlorprop-P & 1.25 & $331 / 356$ \\
\hline MCPA/dichlorprop-P & 1.75 & $464 / 499$ \\
\hline MCPA/mecoprop-P & 1.25 & $338 / 381$ \\
\hline MCPA/mecoprop-P & 1.75 & $473 / 534$ \\
\hline Tribenuron-methyl ${ }^{1)}$ & $7 \mathrm{~g}$ & 5.3 \\
\hline
\end{tabular}

${ }^{1)}$ Non-ionic surfactant ('Citowett') $0.05 \%$ was added to the spray solution (water volume $2001 \mathrm{ha}^{-1}$ ). 
included in the experiments. The objective was to investigate whether the positive results of reducing the recommended doses of racemic mixtures (SALONEN 1992a) would apply also to new formulations. Fluroxypyr was introduced into the official screening trials in Finland in 1982 as a new herbicide for weed control in cereal crops, with particular effect on Galium aparine L. (PAUL et al. 1985).

Treatments were arranged as a randomized complete block design with four replicates. Herbicides were applied at the 3- to 4- leaf stage of the crop (Zadoks' scale 13-15 (ZADOKS et al. 1974)) with a portable van der Weij propane sprayer that delivered $2001 \mathrm{ha}^{-1}$ spray solution at a pressure of 300 $\mathrm{kPa}$.

Herbicides were applied between the end of May and mid-June, about one month after sowing. The temperature at the time of application ranged from 10 to $25^{\circ} \mathrm{C}$, and the relative humidity from 33 to $77 \%$.

The emergence of crops and weeds were monitored before the herbicide application. Crop development (growth stages) and weed emergence were recorded.

Weeds were assessed in $0.25 \mathrm{~m}^{-2}$ sample plots. Annual dicot weeds were counted 0-1 days before spraying (with some exceptions of 2-4 days delay). Furthermore, the weed infestation (number and airdry weight per unit area) was assessed one month after spraying and at harvest. The relative number of emerged weeds at the time of spraying herbicides was calculated by comparing the number of weeds $\left(\right.$ No. $\mathrm{m}^{-2}$ ) at spraying and one month later. Crop yield results are given at $15 \%$ moisture content.

The impact of different control regimes on the subsequent weed infestation was assessed one year after the 3-year trial period in 1992. Weeds were counted at the time of spraying herbicides in spring cereal fields.

\section{Statistical analysis}

Analysis of variance was applied to weed and crop data by introducing Year as a within-subject factor and Site, Treatment and Block as between-subject factors. The random factor Block was nested in the site. The biomass of weeds, as a dependent variable, was transformed with the common logarithm $\log (y+1)$ to achieve normal distribution and homogeneity of variances. Weed density (No. $\mathrm{m}^{-2}$ ) was transformed with square root. The data from unsprayed plots were excluded from the final statistical analyses. The effect of herbicide dose reduction was tested with single degree-of-freedom contrasts. The effect of weed infestation (density, biomass) on crop yield was tested with regression analysis. Statistical analyses were done with the General Linear Models procedure of the SAS statistical package (SAS Institute Inc. 1990).

\section{Results}

\section{Occurrence of weeds}

Weed density at the time of herbicide application varied within the range of 7-702 weeds $\mathrm{m}^{-2}$ (Fig. 1). Also, the relative number of weeds which emerged before herbicide application, compared with the number of weeds per unit area one month later, varied considerably (Fig. 2). On average, $72 \%$ of the annual dicotyledonous weeds emerged before spraying. Crop plants usually reached at least the second leaf stage (Zadoks' scale 12-13) before the first flush of weeds. Most weed seedlings were between the cotyledon stage and the first true-leaf stage at the time of herbicide application.

The predominant weed species in the experimental fields were typical of Finnish cereal fields (c.f. ERVIÖ and SALONEN 1987). The weed populations varied between sites (Table 2) and, to some extent, between years at the same site. The most frequent and abundant weed species were Chenopodium album L., Fumaria officinalis L., Lamium L. spp., Stellaria media (L.) Vill., Matricaria L. spp.(including Tripleurospermum inodorum Schultz Bip.) and Viola arvensis Murray. Volunteer turnip rape (Brassica rapa L. subsp. oleifera DC.) occurred in those fields (LOU, SAT) where there were trials with turnip rape some years before the experiment.

The weed biomass (air-dry weight, DW) in the untreated plots ranged from 0.4 (SE 0.2) to 61.5 (SE 
a)

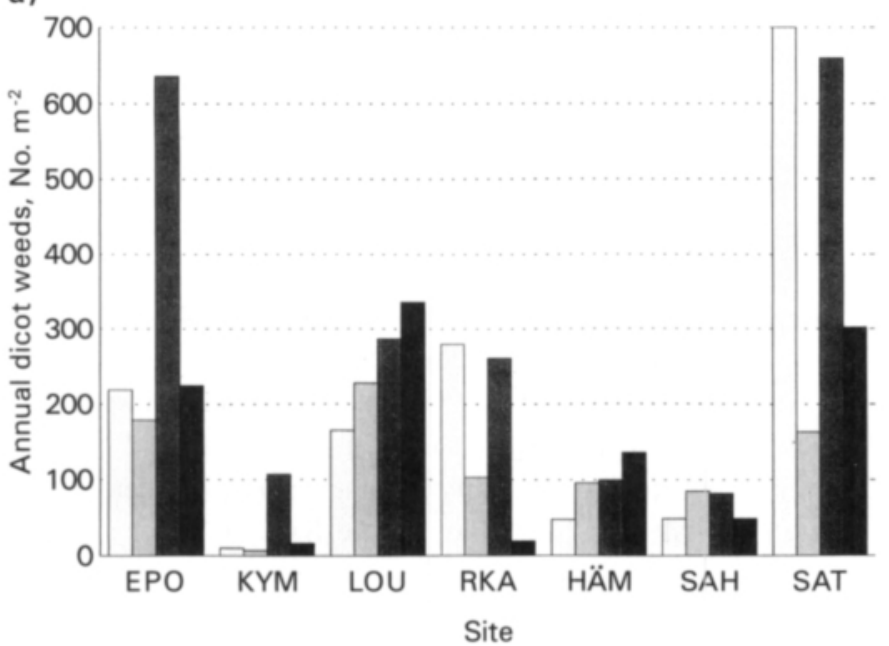

b)

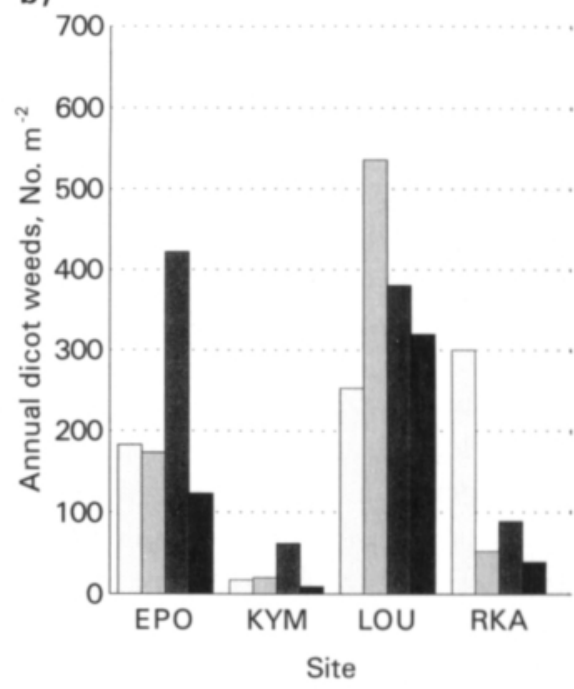

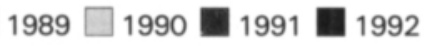

Fig. 1. Weed infestation in the experimental fields at the time of herbicide application in a) spring wheat and b) spring barley. The experimental sites are: $\mathrm{EPO}=$ Ylistaro, $\mathrm{KYM}=$ Anjalankoski, $\mathrm{LOU}=$ Mietoinen, $\mathrm{RKA}=$ Jokioinen, $\mathrm{HÄM}=\mathrm{Pälkäne}$, $\mathrm{SAH}=$ Mouhijärvi, SAT $=$ Kokemäki.

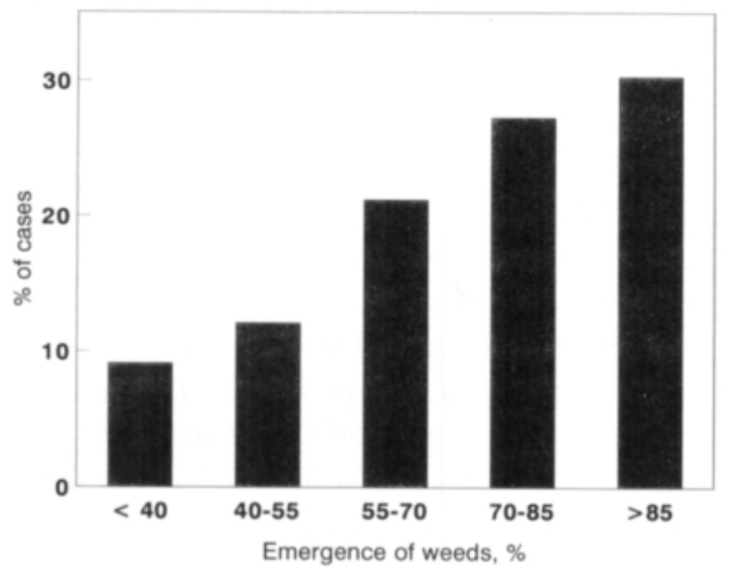

Fig. 2. Weed emergence in unsprayed plots at the time of herbicide application given as a percentage (five classes) of the weed density $\left(\mathrm{No}^{-2} \mathrm{~m}^{-2}\right)$ one month later in 33 spring cereal experiments in 1989-1991.
Table 2. Predominant weed species in the experimental fields.

\begin{tabular}{|c|c|c|c|c|}
\hline Site & & Weed & pecies ${ }^{1)}$ & \\
\hline $\begin{array}{l}\text { Anjalan- } \\
\text { koski (KYM) }\end{array}$ & CHEAL & FUMOF & GALSS & POLCO \\
\hline $\begin{array}{l}\text { Jokioinen } \\
\text { (RKA) }\end{array}$ & CHEAL & LAMSS & STEME & VIOAR \\
\hline $\begin{array}{l}\text { Kokemäki } \\
\text { (SAT) }\end{array}$ & BRSRO & CHEAL & THLAR & VIOAR \\
\hline $\begin{array}{l}\text { Mietoinen } \\
\text { (LOU) }\end{array}$ & BRSRO & FUMOF & LAMSS & STEME \\
\hline $\begin{array}{l}\text { Mouhijärvi } \\
\text { (SAH) }\end{array}$ & CHEAL & MYOAR & TRFPR & VIOAR \\
\hline $\begin{array}{l}\text { Pälkäne } \\
\text { (HÄM) }\end{array}$ & CHEAL & MATSS & STEME & VIOAR \\
\hline $\begin{array}{l}\text { Ylistaro } \\
\text { (EPO) }\end{array}$ & LAMSS & MATSS & POLCO & STEME \\
\hline
\end{tabular}

1) BAYER codes for weeds (BAYER 1992): BRSRO = Brassica rapa ssp. oleifera $($ volunteer), CHEAL $=$ Chenopodium album, FUMOF $=$ Fumaria officinalis, GAESS $=$ Galeopsis spp., GALS $=$ Galium spp., LAMSS $=$ Lamium spp., MATSS $=$ Matricaria spp., POLCO $=$ Fallopia convolvulus, STEME $=$ Stellaria media, THLAR $=$ Thlapsi arvense, $\mathrm{TRFPR}=$ Trifolium pratense, $\mathrm{VIOAR}=$ Viola arvensis. 
12.2) $\mathrm{g} \mathrm{DW} \mathrm{m}^{-2}$ one month after herbicide application, and from 1.8 (SE 0.9) to 116.3 (SE 7.7) g DW $\mathrm{m}^{-2}$ at harvest. Biomass production varied considerably between weed species. Consequently, the total weed biomass in unsprayed plots, one month after spraying, weakly correlated $(r=0.48)$ with the total weed density at spraying. The most competitive weed species producing the highest biomass per plant were volunteer turnip rape $(0.60 \mathrm{~g}$ DW plant $\left.^{-1}\right)$, Galeopsis L. spp. (0.27 $\mathrm{g} \mathrm{DW}$ plant $\left.^{-1}\right)$ and Fallopia convolvulus (L.) A. Löve $(0.15 \mathrm{~g} \mathrm{DW}$ plant $\left.^{-1}\right)$. The biomass production of barley averaged $1.10 \mathrm{~g} \mathrm{plant}^{-1}$ and that of wheat $1.02 \mathrm{~g} \mathrm{plant}^{-1}$ at the four sites where both crops were grown in the same field.

\section{Herbicide efficacy}

Generally, all herbicides were effective when applied at the lowest recommended dose, and 30\% dose reduction reduced the efficacy, on average, by less than 10 percentage units (Fig. 3). However, a significant $(\mathrm{P}<0.001)$ Year*Site*Treatment interaction was detected (Table 3). This indicates that there were differences in the effectiveness of weed control between sites and between years within a site. Tribenuron-methyl was the most effective herbicide in most trials (Fig. 4), particularly when Matricaria spp. and Lamium spp. (EPO, LOU) were the predominant weed species.

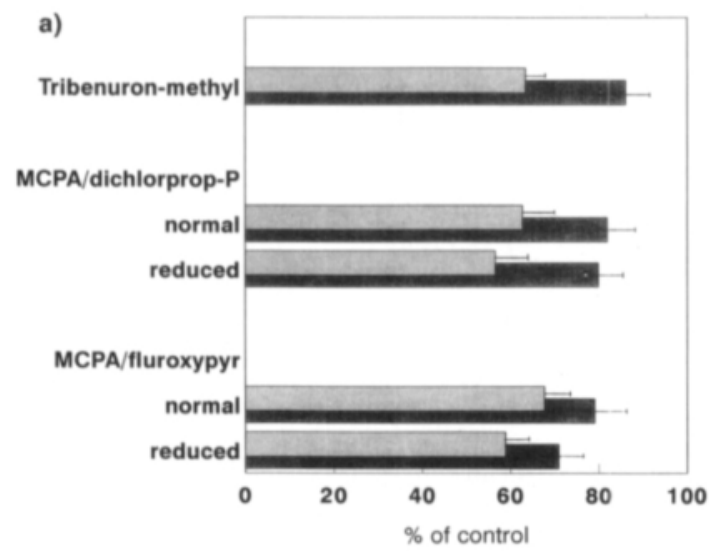

The reduction in herbicide efficacy was considered significant if $30 \%$ dose reduction caused more than $15 \%$ reduction in efficacy (on \%-scale) compared with the efficacy achieved with the recommended dose. In wheat trials such a reduction $(>15 \%)$ in the biomass-based efficacy occurred in $29 \%$ of plots treated with MCPA/mecoprop-P, and in $14 \%$ of plots treated with MCPA/fluroxypyr. The corresponding figures for barley trials were $8 \%$ with MCPA/dichlorprop-P and $19 \%$ with MCPA/fluroxypyr.

To describe the probability of achieving a certain level of weed control, herbicide efficacy was calculated for each treatment within each replicate and the results were ranked in four efficacy classes (Fig. 5). Accordingly, treatment with reduced herbicide doses still provided at least $70 \%$ control in $70-89 \%$ of plots monitored. At the recommended herbicide doses the $70 \%$ efficacy level was reached in 78$91 \%$ of cases.

Weed biomass in sprayed crop stands one month after herbicide treatment was less than $15 \mathrm{~g} \mathrm{DW} \mathrm{m}^{-2}$ in every trial. Dry weight of crop plants in unsprayed plots averaged 506 (SE 24) $\mathrm{g} \mathrm{DW} \mathrm{m}^{-2}$ in barley and 482 (SE 15) $\mathrm{g} \mathrm{DW} \mathrm{m}^{-2}$ in wheat. Dry weight of weeds was significantly $(\mathrm{P}<0.01)$ higher in unsprayed than in sprayed plots. To simplify the ANOVA analyses, data from the unsprayed plots were not included in the final analyses (Table 3). Only in some fields was the weed biomass signifi-

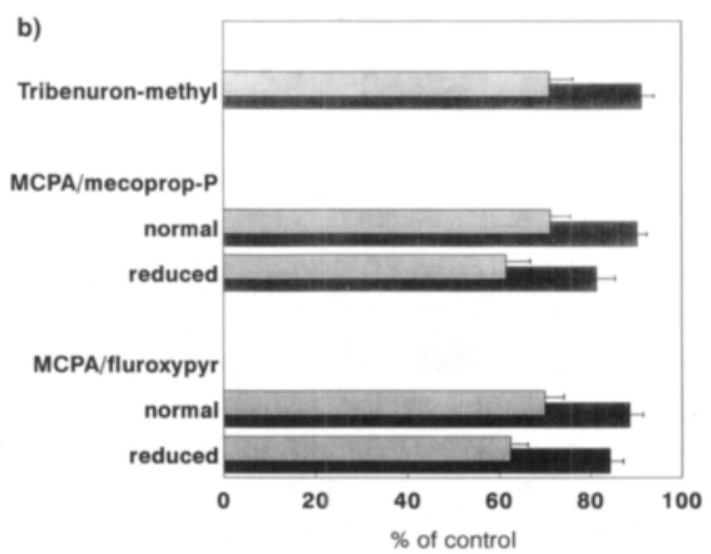

Fig. 3. Efficacy of herbicides determined as \% reduction of weed density (light bar) and dry weed biomass (dark bar). The mean efficacy and the SE of the mean in a) 12 spring barley trials and b) 21 spring wheat trials during 1989-1991. 
a)
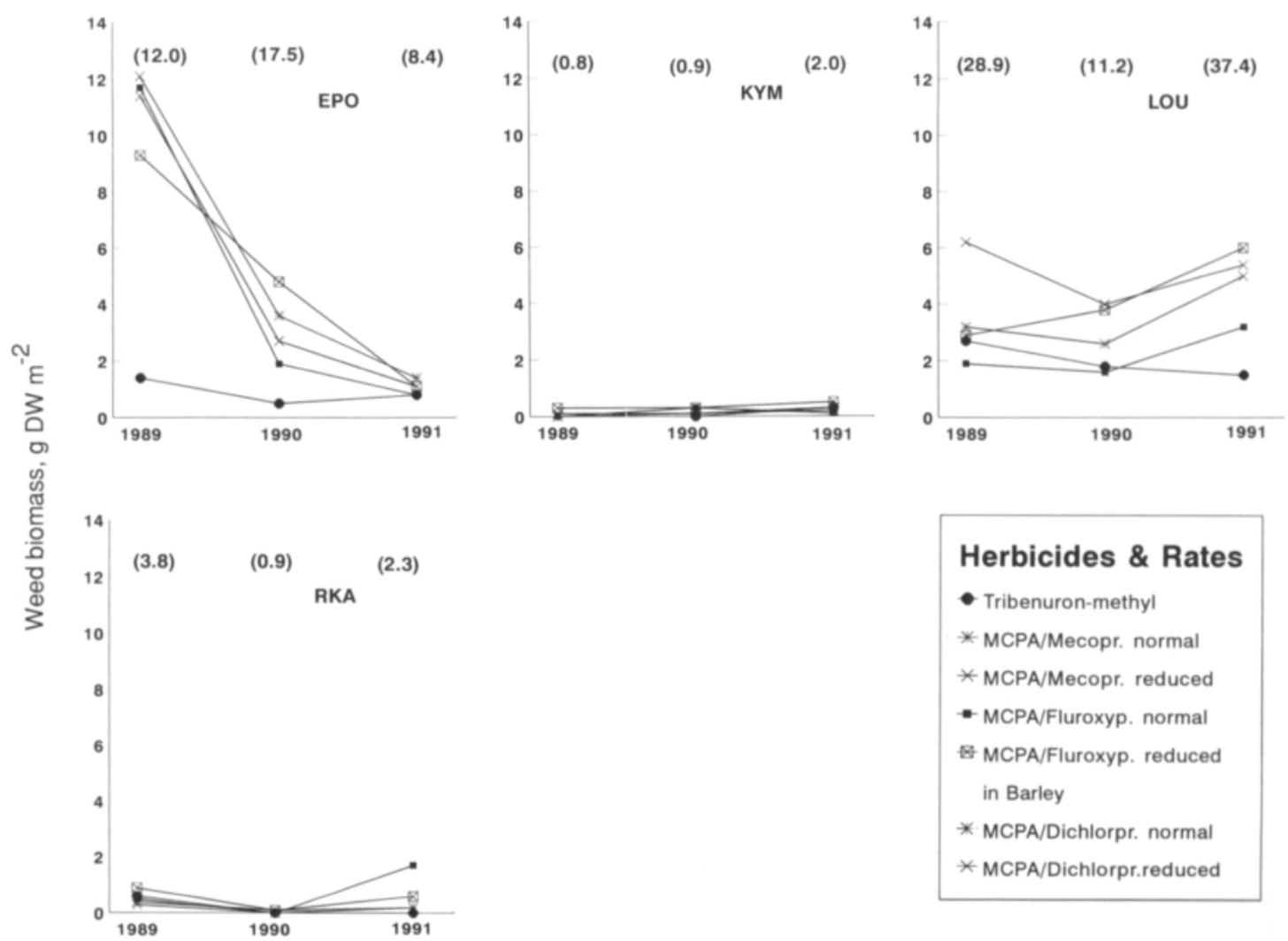

Herbicides \& Rates

- Tribenuron-methyl

* MCPA/Mecopr. normal

* MCPA/Mecopr. reduced

- MCPA/Fluroxyp. normal

MCPA/Fluroxyp. reduced in Barley

* MCPA/Dichlorpr. normal

* MCPA/Dichlorpr.reduced

b)
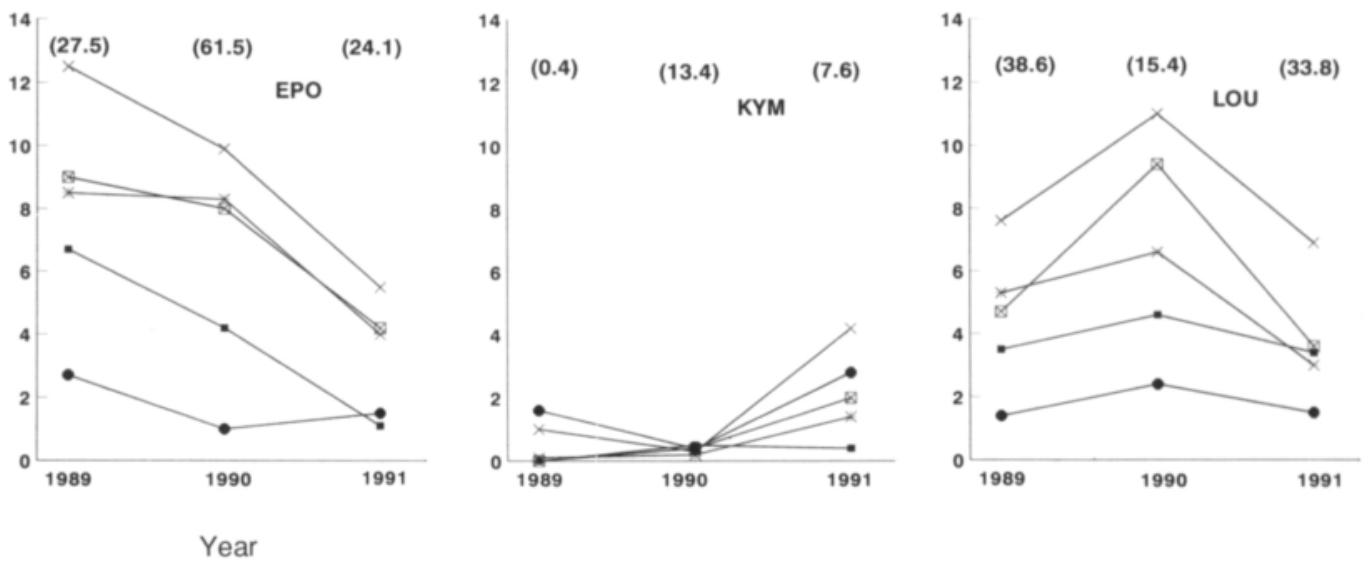
Fig. 4b) continues

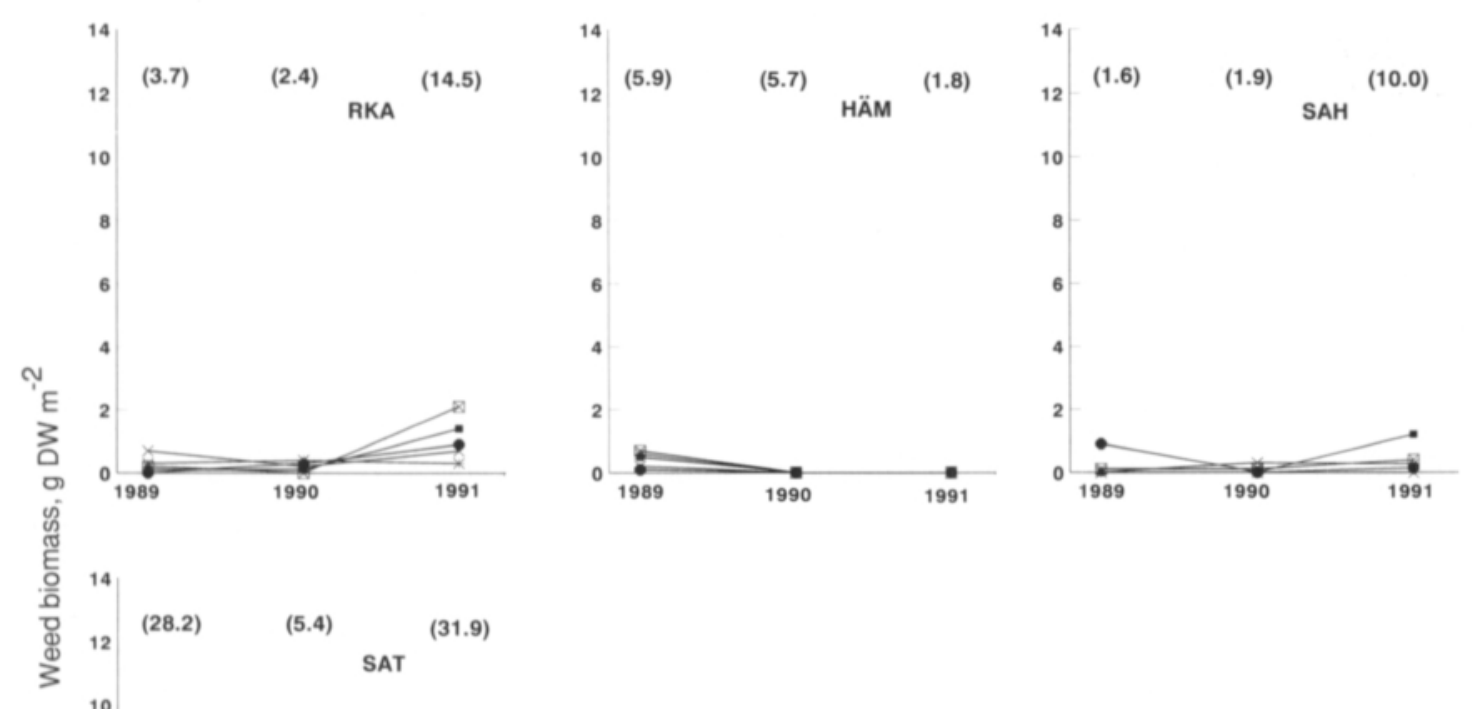

Fig. 4. Comparison of the remaining weed biomass in 1989-1991 in a) spring barley and b) spring wheat one month after treatment with different herbicide formulations and doses. The figures in paranthesis indicate the air-dry weed biomass $\left(\mathrm{g} \mathrm{m}^{-2}\right)$ in the unsprayed plots each year. The experimental sites are: EPO $=$ Ylistaro, $\mathrm{KYM}=$ Anjalankoski, LOU $=$ Mietoinen, RKA $=$ Jokioinen, $\mathrm{HÄM}=$ Palkäne, $\mathrm{SAH}=$ Mouhijärvi, $\mathrm{SAT}=$ Kokemaki.

cantly higher in the plots treated with reduced doses than in the plots treated with normal doses. In general, weeds produced more biomass in wheat stands than in barley stands (Fig. 4).

The dose reduction of MCPA/mecoprop-P decreased the effect of control particularly against Myosotis arvensis (L.) Hill, Matricaria spp., Polygonum L. spp. and Viola arvensis. Similarly, the dose reduction of MCPA/fluroxypyr significantly decreased (>10\%-units) the efficacy against $F u$ maria officinalis, Matricaria spp., Polygonum spp. and Viola arvensis. Conclusions concerning MCPA/dichlorprop-P were not drawn due to the limited number of observations.

\section{Crop-weed interactions}

The yield of spring barley and spring wheat averaged 4,900 kg ha- and 3,700 $\mathrm{kg} \mathrm{ha}^{-1}$, respectively.
In the trial plots treated with herbicides the mean yield of wheat was $1.9 \%$ higher and barley yield was $4.0 \%$ higher than in untreated plots. The monetary value of such a yield increase ranges from FIM 150 to FIM 300 which is sufficient to cover the average cost of (FIM 100) herbicides for broadleaved weed control. Herbicide treatment did not reduce crop yield significantly $(\mathrm{P}<0.05)$ in any trial.

There was no significant difference in the mean crop yield from plots which received a recommended dose and those which received a reduced dose of herbicide. Only in one trial from 21 wheat trials did the dose reduction of MCPA/mecoprop-P result in a significantly $(\mathrm{P}<0.01)$ lower wheat yield, and once, in the same trial, with a reduced dose of MCPA/fluroxypyr $(\mathrm{P}<0.02)$.

The proportion of weed biomass from the total vegetative biomass of cereal fields was relatively low (Table 4). 
Table 3. Repeated measurements analysis of variance (ANOVA) of weed biomass $\log (\mathrm{Y}+1)$ in sprayed plots in spring barley at four sites and in spring wheat at seven sites. Trials were repeated for three years. Air-dry weight of weeds was measured one month after herbicide application.

\begin{tabular}{llll}
\hline Crop & $\begin{array}{l}\text { Degrees Type III } \\
\text { of } \quad \text { Mean }\end{array}$ & F-test \\
Source of variation & freedom Square & &
\end{tabular}

\section{Spring barley}

Between-subject effect

\begin{tabular}{|c|c|c|c|c|}
\hline Site & 3 & 3.64 & 28.83 & $<0.001$ \\
\hline Error (1) & 10 & 0.13 & & \\
\hline Treatment & 4 & 0.21 & 8.82 & $<0.001$ \\
\hline Site* treatment & 12 & 0.11 & 4.72 & $<0.001$ \\
\hline Error (2) & 40 & 0.02 & & \\
\hline \multicolumn{5}{|l|}{ Within-subject effect } \\
\hline Year & 2 & 0.61 & 26.41 & $<0.001$ \\
\hline Year*site & 6 & 0.50 & 21.31 & $<0.001$ \\
\hline Error (3) & 20 & 0.02 & & \\
\hline Year*treatment & 8 & 0.02 & 1.43 & 0.20 \\
\hline Year*site*treatment & 24 & 0.05 & 2.91 & $<0.001$ \\
\hline Error (4) & 80 & 0.02 & & \\
\hline \multicolumn{5}{|l|}{ Spring Wheat } \\
\hline \multicolumn{5}{|l|}{ Between-subject effect } \\
\hline Site & 6 & 3.90 & 36.96 & $<0.001$ \\
\hline Error (1) & 18 & 0.11 & & \\
\hline Treatment & 4 & 0.29 & 15.51 & $<0.001$ \\
\hline Site*treatment & 24 & 0.12 & 6.38 & $<0.001$ \\
\hline Error (2) & 72 & 0.02 & & \\
\hline \multicolumn{5}{|l|}{ Within-subject effect } \\
\hline Year & 2 & 0.08 & 1.68 & 0.16 \\
\hline Year*site & 12 & 0.31 & 6.80 & $<0.001$ \\
\hline Error (3) & 36 & 0.05 & & \\
\hline Year*treatment & 8 & 0.02 & 1.80 & 0.56 \\
\hline Year*site*treatment & 48 & 0.03 & 1.30 & 0.12 \\
\hline Error (4) & 144 & 0.03 & & \\
\hline
\end{tabular}

Correlation between weed biomass at harvest and crop yield was weak $(\mathrm{r}<-0.50)$. Graphing data did not reveal any clear relationship between weed biomass and crop yield. The relationship between yield response and weed infestation (density, biomass) was analyzed with linear and non-linear regression. In these analyses the weed infestation accounted for less than $10 \%$ of the total variation in
Table 4. Proportion of weed biomass out of the total vegetative biomass in unsprayed and sprayed plots of spring barley and spring wheat. Assessments were made one month after herbicide application and at harvest. Mean percentage of 12 trials in spring barley and 21 trials in spring wheat in 19891991.

\begin{tabular}{lcc}
\hline & \multicolumn{2}{c}{ Weed biomass, \% $( \pm \mathrm{SE})$} \\
\cline { 2 - 3 } $\begin{array}{l}\text { Crop } \\
\text { Treatment }\end{array}$ & $\begin{array}{c}\text { One month } \\
\text { after spraying }\end{array}$ & At harvest \\
\hline Spring barley & & \\
unsprayed & $2.2(0.5)$ & $3.1(0.8)$ \\
sprayed & $0.5(0.1)$ & $0.4(0.1)$ \\
Spring wheat & & \\
unsprayed & & $3.6(0.6)$ \\
sprayed & $3.4(0.5)$ & $0.6(0.1)$ \\
\hline
\end{tabular}

crop yield. Thus, no reliable threshold value between weed infestation and crop yield response was found.

\section{Impact of weed control on the subsequent weed infestation}

The weed density in 1992, pooled across the sites, was significantly $(\mathrm{P}<0.05)$ higher in plots not sprayed with herbicide ( 158 weeds $\left.\mathrm{m}^{-2}\right)$ than in sprayed plots ( 99 weeds $\mathrm{m}^{-2}$ ). Contrast comparison by site revealed no statistically significant $(\mathrm{P}<0.05)$ differences in the weed densities following from the recommended and the reduced rate applications of any herbicide formulation.

The subsequent effect of herbicide treatments on the weed infestation at spraying in the following years was analyzed with a repeated measurements analysis starting from 1990, one year after the start of the experiment, and including data from 1991 and 1992. A significant difference in weed densities in the unsprayed and sprayed plots was detected, but there was no significant $(\mathrm{P}<0.05)$ difference between weed densities in sprayed plots.

Significant changes in the species composition of weed populations due to the chemical control were not found. The start of the growing season in 1992 was extremely dry, and weed densities were low even in unsprayed plots. 
a)

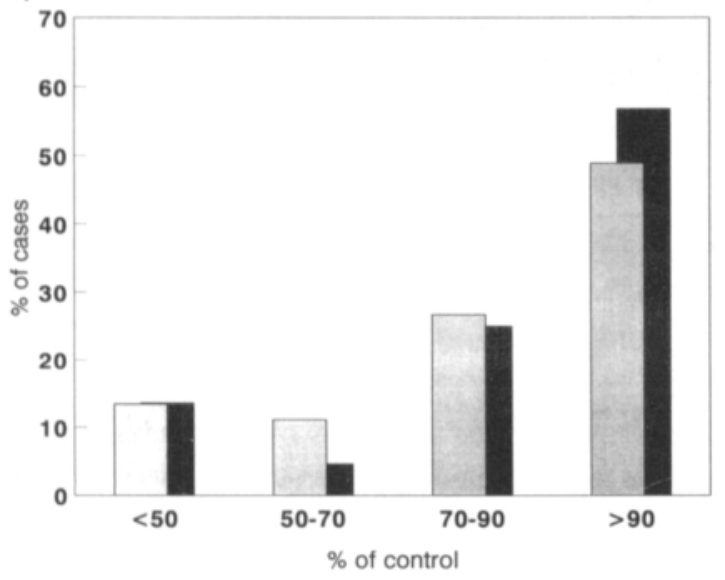

c)

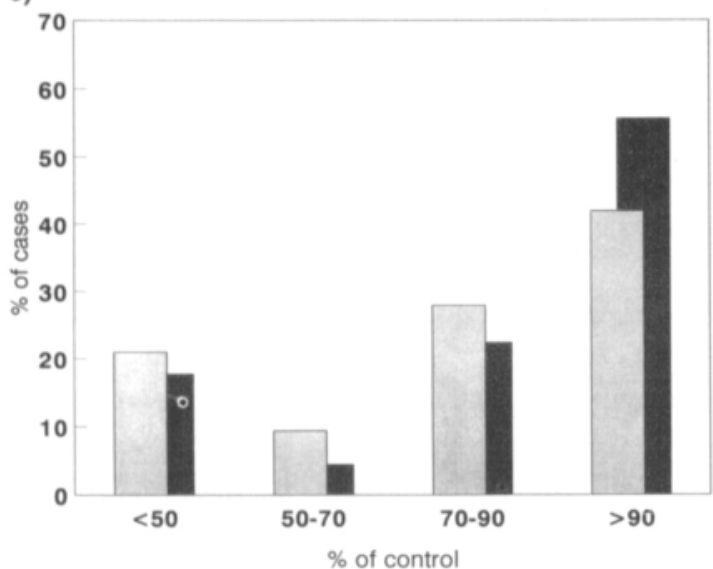

b)

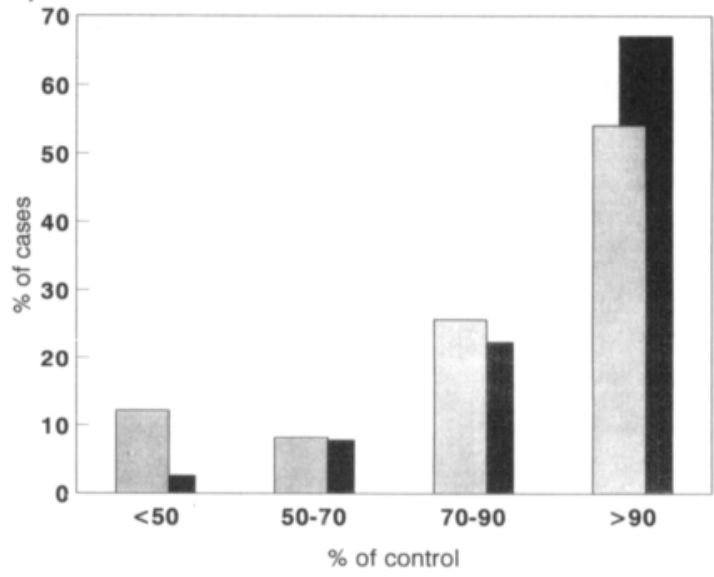

d)

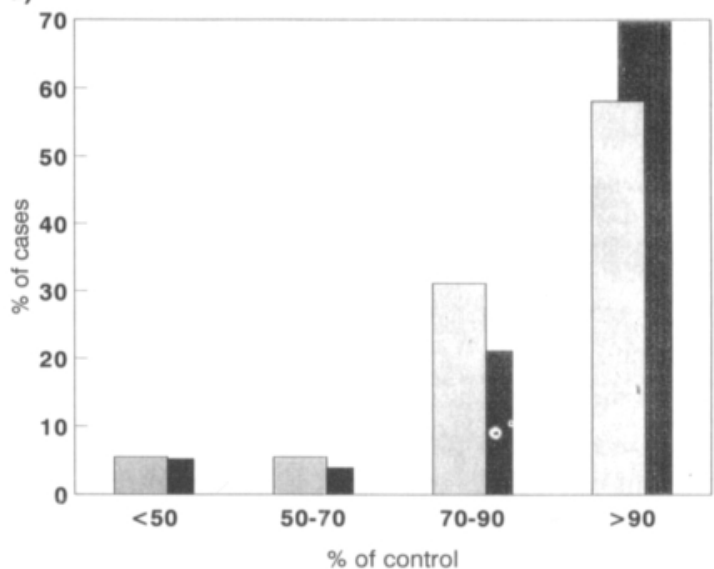

Fig. 5. Distribution of observations into four herbicide efficacy classes determined according to the \% reduction of weed biomass compared with that in the unsprayed plots. The efficacy achieved with the reduced (light bar) and the recommended (dark bar) doses of a) MCPA/dichlorprop-P in spring barley, b) MCPA/mecoprop-P in spring wheat, c) MCPA/fluroxypyr in spring barley and d) MCPA/fluroxypyr in spring wheat.

\section{Discussion}

Differential sensitivity of weed species to herbicides and species-specific dose responses were detected. The results are in accordance with those from earlier studies (e.g. PALLUTT 1988, SALONEN 1992a) and advocate careful annual decision-making for chemical control of weeds.

All herbicide formulations were found appropriate for use in fields of spring cereals in terms of weed-kill and crop safety. Tribenuron-methyl provided, on average, the best weed control (Fig. 3). MCPA/fluroxypyr had no clear advantage over other herbicides since Galium L. spp. did not occur frequently in the trials.

Herbicide formulations and the time of application (related to crop growth) were predetermined in our experimental protocol and not selected according to the prevailing weed species and their growth stages. Herbicide application according to crop growth stage resulted in low herbicide efficacy in some trials, particularly in terms of the effect on weed density (Fig. 3). This was due to late emerging weed seedlings, particularly in sparse crop stands. The delay in weed emergence was typical of dry growth conditions. Delayed herbicide applica- 
tion within the recommended treatment interval would obviously have given better efficacy in such situations. However, the time of application is not considered an equally important factor as the choice of herbicide (JUNNILA 1990).

The competition pressure of the annual dicotyledonous weeds was relatively low, and their proportion of the total vegetative biomass was often negligible compared with the crop biomass. This was evidently a consequence of the earlier emergence of the crop plants relative to the weeds. It is suggested that the relative time of emergence is an important factor in crop-weed competition (e.g., HÅKANSSON 1983, CousENS et al. 1987, KROPFF 1988).

Crop yield responses to chemical weed control were small at normal and reduced herbicide doses. The largest yield increases, over yields from unsprayed plots, with herbicide application were achieved at LOU in 1989, where volunteer oilseed rape was the main weed species. Generally, the weed biomass was negligible compared with crop biomass. Consequently, no reliable relationship between weed infestation and yield response was established.

The herbicide rates applied were appropriate, since herbicide application did not cause any significant reductions in crop yields. The only visual phytotoxic symptom was a typical transient discoloration of crop foliage caused by tribenuronmethyl. In contrast, herbicide treatments have been shown to reduce crop yields (JENSEN 1985, DAVIES and WhitiNG 1990, SALONEN 1992b), particularly when unnecessarily high herbicide rates are applied. MAYES (1980) compared herbicide applications, with products based on phenoxy alkanoic acids, over a range of cereal growth stages. He concluded that, in the absence of weeds, crop yields were not depressed following application of herbicides at their recommended rates before the first node stage of crop. However, incidence of yield reduction was more frequent when high rates were applied at late crop growth stages.

Official recommendations for herbicide doses could be reduced by approximately $30 \%$ provided that conditions for the use of low doses were clearly stated on product labels. Failures in chemical weed control are likely to increase if farmers use reduced herbicide doses incautiously. The reductions in efficacy (Figs. 3, 4 and 5) will not inevitably lead to any long-term increase in weed infestation nor to crop yield reductions, since the current weed infestation and its influence on cereal stands is often low even in unsprayed fields (ERVIÖ et al. 1991). However, crop cover and evenness of crop stands are important factors in determining the optimal dose of herbicides (NIEMANN 1990).

Recommended rates of herbicide application are still needed against relatively tolerant weed species and in delayed applications against more developed weed seedlings. The product labels should, however, include some information about the possibilities to reduce doses. Primarily, these recommendations should be related to weed species. The available information about dose responses of different weed species is relatively comprehensive. Secondly, the precise time of herbicide application, during the early stages of weed growth, should be emphasized more than the crop growth stage.

A wide range of weed densities was recorded in the trials. Any clear tendency towards increasing weed densities could not be detected even in unsprayed plots within the 4-year recording period (Fig. 1). This was partly due to the extreme drought in 1992, which apparently hampered the weed emergence. Considerable and nonpredictable annual variation in weed density in spring cereal experiments has also been recorded e.g. in Norway (FYKSE 1993).

Reduced herbicide doses maintained the weed densities at the same level as the normal doses. Similar results were reported from Denmark by JENSEN (1991) who compared the effects of normal and a half normal doses of herbicides in spring barley fields over ten years. One explanation for good results with reduced herbicide doses is that reduced doses have been shown to suppress weed seed production to the same extent as normal doses (PEDERSEN and RASMUSSEN 1990, ANDERSSON 1993, RASMUSSEN 1993).

No reliable density-based threshold values for chemical weed control were established either in this study or in earlier experiments (BLEIHOLDER and NUYKEN 1986, DAVIES et al. 1989, ERVIÖ et al. 1991). A reduction in the rates of application of 
herbicides would represent a feasible means of reducing their use, with all the accompanying benefits for the environment, while maintaining weed infestation in cereal fields at the current low levels. Unfortunately, not all treatments are profitable in terms of crop yield increase (JENSEN 1985, ERVIÖ et al. 1991).

Although some results are pooled across years and sites, the main conclusion reached from the series of field experiments is that the decision-making for chemical weed control is a site-specific problem, and even seasonal variations should be considered. A broad range of herbicides is available for diverse weed control problems in cereals. The profitability of cereal production can be increased by choosing appropriate herbicide formulations, and by applying timely optimal doses.

Acknowledgements. I thank the representatives of BASF and DowElanco for providing the herbicide formulations at my disposal.

\section{References}

ANDERSSON, L. 1993. Inverkan av MCPA på fröproduktionen hos några ogräsarter. Proc. 34:e svenska växtskyddskonf., Ogräs och ogräsbekämpning. p. 49-58.

BaAndRuP, M. \& BallegaARD, T. 1989. Three years field experience with an advisory computer system applying factor-adjusted doses. Proc. Brighton Crop Prot. Conf. Weeds. 2: 555-560.

BAYER 1992. Important crops of the world and their weeds. 2nd ed. Bayer AG. Leverkusen. 1681 p.

BleiHOlder, H. \& NuYKen, W. 1986. Neue Ansätze zur Darstellung und Interpretation des Zusammenhanges zwischen den Deckungsgrad der Unkräuter und dem Ertrag von Getreide. Proc. EWRS Symp. Economic Weed Control. p. 331-336.

Cousens, R., Brain, P., O'Donovan, J.T. \& O'Sullivan, A. 1987. The use of biologically realistic equations to describe the effects of weed density and relative time of emergence on crop yield. Weed Sci. 35: 720-725.

DAVIES, D.H.K. \& WhITING, A.J. 1990. Effect of reduced herbicide dose on weed growth and crop safety in cereals and consequences for grain quality and harvesting. Proc. EWRS Symp. Integrated Weed Management in Cereals. p. 331-336.

—, Whiting, A.J. \& Whyтоск, G.M. 1989. Yield responses to herbicide use and weed levels in winter wheat and spring barley in Scottish trials and consequences for economic models. Proc. Brighton Crop Prot. Conf. Weeds. 3: 955-960.

ERviö, L.-R. \& SAlonen, J. 1987. Changes in the weed population of spring cereals in Finland. Ann. Agric. Fenn. 26: 201-226.

— , Tanskanen, T. \& Salonen, J. 1991. Profitability of chemical weed control in spring cereals. Ann. Agric. Fenn. 30: 199-206.

Ferguson, D.T., Schehl, S.E., Hageman, L.H., LePONE, G.E. \& CARRARO, G.A. 1985. DPX-L5300 - a new cereal herbicide. Proc. Brit. Crop Prot. Conf. - Weeds. 1: 43-48.

FOGELFORS, H. 1990. Different doses of herbicide for control of weeds in cereals - final report from the long-term series. Proc. 31st Swedish Crop Prot. Conf. p. 139-151.
FYKSE, H. 1993. Dynamics of weeds in long-term experiments in spring cereals. Proc. EWRS Symp. Quantitative Approaches in Weed and Herbicide Research. 2: 689696.

HÅKANSSON, S. 1983. Competition and production in shortlived crop-weed stands. Swedish Univ. Agric. Sci., Dept. Plant Husb., Report 127. Uppsala. 85 p.

HynNinen, E.-L. \& BlomQvist, H. 1993. Pesticide sales in Finland 1992. Kemia-Kemi. 20: 535-537.

JENNÉuS, B. 1991. Reducerade doser av ogräsmedel i stråsäd. Resultat från demonstrationsodlingar. Proc. 32:a svenska växtskyddskonf., Ogräs och ogräsbekämpning. p. 39-51.

JENSEN, P.K. 1985. A review of yield responses to weed control in one thousand spring barley experiments. Proc. 1985 Brit. Crop Prot. Conf. - Weeds. 2: 687-692.

- 1991. Behov og økonomi ved ukrudtsbekæmpelse i landbrugsafgøder. Møder om planteværn 1991, Landbrugsafgrøder. p. 14-16.

JUNNILA , S. 1990. Influence of spraying time on herbicide efficacy in spring cereals. Proc. EWRS Symp. Integrated Weed Management in Cereals. p. 375-382.

KEMMER, A. \& HURLE, K. 1990. Untersuchungen zur Reduzierung des Herbizidaufwandes bei der Unkrautbekämpfung in Getreide. Proc. 47. Deutsche Pfl.schutzTagung. Mitt. Biol. Bundesanst. f. Land- u. Forstw., Heft 266. p. 377.

KROPFF, M.J. 1988. Modelling the effects of weeds on crop production. Weed Res. 28: 465-471.

KUDSK, P. 1989. Experiences with reduced herbicide doses in Denmark and the development of the concept of factor-adjusted doses. Proc. Brighton Crop Prot. Conf. Weeds. 2: 545-554.

Markiula, M., Titttanen, K. \& Vasarainen, A. 1990. Torjunta-aineet maa- ja metsätaloudessa 1953-1987. Maatalouden tutkimuskeskus, Tiedote 2/90. 58 p.

MAYES, A.J. 1980. The influence of application time on cereal yield of products based on substituted phenoxy alkanoic herbicides. Proc. Brit. Crop Prot. Conf. - Weeds. 1: 77-83. 
NiEmanN, P. 1990. Zur Häufigkeit von Bestandeslücken und deren Bedeutung für die Verunkrautung. Z. Pfl.krankh. Pfl.schutz, Sonderh. 12: 59-69.

PALluTt, B. 1988. Beiträge zur integrierten Unkrautbekämpfung im Getreideanbau. Akad. Landw. der DDR, Berlin. 129 p. (Diss.).

PAul, J.A., Sutton, P.B., Skidmore, A.M. \& Score, D.J. 1985. FF4014: a new broad spectrum cereal herbicide based on fluroxypyr. Proc. Brit. Crop Prot. Conf. Weeds. 3: 939-946.

Pedersen, J.O. \& RASmussen, I.A. 1990. Herbiciders inflydelse på ukrudets fröproduktion. Proc. 7. Danske Plantev.konf. 1990, Ukrudt. p. 73-83.

Proven, M.J., Courtney, A., Picton, J., Davies, D.H.K. \& Whiting, A.J. 1991. Cost-effectiveness of weed control in cereals - systems based on thresholds and reduced rates.Proc. Brighton Crop Prot. Conf. - Weeds. 3: 12011208.

RASMUSSEN, I. 1993. Seed production of Chenopodium album in spring barley sprayed with different herbicides in normal to very low doses. Proc. EWRS Symp. Quantitative Approaches in Weed and Herbicide Research. 2: 639-646.

SALONEN, J. 1992a. Efficacy of reduced herbicide doses in spring cereals of different competitive ability. Weed Res. 32: 483-491.
- 1992b. Yield responses of spring cereals to reduced herbicide doses. Weed Res. 32: 493-499.

SAS Institute Inc. 1990. SAS/STAT® User's Guide, Vers. 6, 4th ed., Vol 2. SAS Inst. Inc. Cary, NC. 848 p.

Squires, N.R.W., RadTKE, M. \& Hunt, B.S. 1987. New formulations of phenoxypropionic herbicides containing only the herbicidally active isomer for the control of broad-leaved weeds in cereals. Proc. 1987 Brit. Crop Prot. Conf. - Weeds. 1: 225-231.

THONKE, K. E. 1991. Political and practical approaches in Scandinavia to reduce herbicide inputs. Proc. Brighton Crop Prot. Conf. - Weeds. 3: 1183-1190.

ZadoKs, J.C., Chang, T.T. \& KonZaK, C.F. 1974. A decimal code for growth stages of cereals. Weed Res. 14: 415421.

Ympäristöministeriö 1992. Ehdotus maaseudun ympäristöohjelmaksi. Ympär.suoj.os., Työryhmämiet. 68/92. Helsinki. 49 p.

Manuscript received September 1993

Jukka Salonen

Agricultural Research Centre of Finland

Institute of Plant Protection

FIN-31600 Jokioinen, Finland 


\title{
SELOSTUS
}

\section{Pienennettyjen herbisidiannosten toimivuus kevätviljojen rikkakasvintorjunnassa}

\author{
JUKKA SALONEN
}

Maatalouden tutkimuskeskus

Kolmevuotisessa (1989-1991) seitsemälle koepaikalle sijoitetussa tutkimuksessa selvitettiin mahdollisuutta pienentäă viljaherbisidien käyttömääräsuositusta. MCPA/diklorproppi-P, MCPA/mekoproppi-P ja MCPA/fluroksipyyri ruiskutettiin kevätvehnä- ja ohrakokeissa pienimmällä suositellulla ja $30 \%$ pienemmällä annoksella. Verrannevalmisteena oli pienannosherbisidi tribenuroni-metyyli. Kolmen koevuoden aikana toteutettiin yhteensä 21 kevätvehnäkoetta ja 11 ohrakoetta.

Rikkakasvien määrä ruiskutushetkellä vaihteli 7-702 $\mathrm{kpl} / \mathrm{m}^{2}$, jolloin rikkakasveista oli taimettunut keskimäärin 72 $\%$ verrattuna kuukauden kuluttua mitattuun rikkakasvien määrään. Rikkakasvien kasvutiheyden perusteella ei voitu ennustaa viljakasvustoon kesän mittaan muodostuvaa rikkakasvimassaa, sillä rikkabiomassan tuotanto vaihteli rikkakasvilajien, viljan kilpailukyvyn ja sääolojen mukaan. Rikkakasvien tuottama ilmakuiva biomassa vaihteli suuresti vuosittain ja koepaikoittain välillä $0.4-61.5 \mathrm{~g} / \mathrm{m}^{2}$ kuukauden kuluttua herbisidiruiskutuksesta ja välillä $1.8-116.3 \mathrm{~g} / \mathrm{m}^{2}$ puintihetkellä.

Herbisidiannoksen vähentäminen $30 \%$ :lla heikensi torjuntatehoa keskimäärin alle $10 \%$-yksikköä. Yli $15 \%$-yksikön tehon heikkeneminen havaittiin kevätvehnäkokeissa MCPA/mekoproppi-P:Ilä $29 \%$ :ssa kokeista ja MCPA/fluroksipyyrillä $14 \%$ :ssa kokeista, sekä ohrakokeissa MCPA/diklorpropilla $8 \%$ :ssa kokeista ja MCPA/fluroksipyyrillä $19 \%$ :ssa kokeista.

Pienemmillä annoksilla herbisidit vähensivät rikkakasvimassaa $75 \%$ ohrakokeissa ja $83 \%$ kevătvehnăkokeissa ruiskuttamattomaan verrattuna. Vaikka suositellun annoksen pienentäminen heikensi toisinaan huomattavasti \%-yksiköissä laskettua torjuntatehoa, ei kasvustoon useinkaan jäänyt viljelykasvin kannalta haitallisia määriä rikkakasveja. Monesti rikkakasvien tuottama biomassa oli ruiskuttamat- tomissakin ruuduissa vähäinen, keskimäärin noin $3 \%$ viljakasvuston kokonaisbiomassasta.

Rikkakasvitorjunnan jälkivaikutus selvitettiin vuonna 1992 laskemalla rikkakasvien määrä ruiskutushetkellä. Ruiskuttamattomissa ruuduissa rikkakasvien lukumäärä $\left(158 \mathrm{kpl} / \mathrm{m}^{2}\right)$ oli keskimäärin suurempi kuin ruiskutetuissa ruuduissa $\left(99 \mathrm{kpl} / \mathrm{m}^{2}\right)$. Eri koepaikkojen välillä oli suuria eroja taimettuneiden rikkakasvien määrässä, mutta herbisidiannoksen vähentäminen ei missään kokeessa lisännyt merkitsevästi rikkakasvien määrää. Alkukesän kuivuus vuonna 1992 haittasi rikkakasvien taimettumista, eikä taimettuneiden rikkakasvien määrä välttämättä kuvannut maan rikkasiemenvarastoa eri koejäsenten välillä.

Rikkakasvien aiheuttamat satotappiot jäivät useimmissa tämän tutkimuksen kenttäkokeissa hyvin pieniksi. Herbisidiruiskutus lisäsi kevätvehnän satoa keskimäärin $1,9 \%$ ja ohran satoa 4,0 \%. Luotettavaa kynnysarvoa herbisidien käytőstä luopumiselle ei kuitenkaan voitu määrittää, sillä rikkakasvien lukumäärä ruiskutushetkellä ei kuvannut niiden kesän kuluessa tuottamaa biomassaa ja siitä aiheutuvaa viljasadon vähentymistä. Kuukauden kuluttua ruiskutuksesta herbisidiä kestäneiden ja ruiskutuksen jälkeen taimettuneiden rikkakasvien tuottama ilmakuiva biomassa oli kaikissa kokeissa alle $15 \mathrm{~g} / \mathrm{m}^{2}$, kun kevätvehnän biomassa oli keskimäärin $482 \mathrm{~g} / \mathrm{m}^{2}$ ja ohran $506 \mathrm{~g} / \mathrm{m}^{2}$.

Tutkimustulokset puoltavat herbisidien myyntipäällyksessä ilmoitettujen annossuositusten pienentämistä noin 30 $\%$ tilanteissa, joissa herbisidi valitaan rikkakasvilajiston mukaan ja ruiskutus ajoitetaan rikkakasvien varhaiselle taimivaiheelle. Erittäin hyväkuntoisessa viljakasvustossa voidaan vähäisiä rikkakasvimääriä torjua vieläkin pienemmällä herbisidimäärällä. Herbisidiannoksen tarkentamisen toivotaan johtavan herbisidien käytön vähentämiseen tavalla, jolla estetään rikkakasvien määrän lisääntyminen pelloilla. 